\title{
The Gaps in the Vocational Education and Training Curricula to Address Aeronautical Industry Needs
}

\author{
Rosa Arnaldo*, Fernando Gómez Comendador \\ Airspace Systems, Air Transport and Airports Department, Universidad Politécnica de Madrid, Madrid, Spain \\ Email address: \\ rosamaria.arnaldo@upm.es (R. Arnaldo), fernando.gcomendador@upm.es (F. G. Comendador) \\ ${ }^{*}$ Corresponding author
}

To cite this article:

Rosa Arnaldo, Fernando Gómez Comendador. The Gaps in the Vocational Education and Training Curricula to Address Aeronautical Industry Needs. International Journal of Education, Culture and Society. Vol. 2, No. 6, 2017, pp. 172-183. doi: 10.11648/j.ijecs.20170206.13

Received: January 9, 2017; Accepted: January 23, 2017; Published: November 28, 2017

\begin{abstract}
Aeronautic Industry has a critical responsibility in facilitating European economic growth and social inclusion providing revenues to otherwise isolated regions and allowing people to enlarge their horizons. According to the EU, currently aeronautics and air transport are key drivers of European cohesion and competitiveness, representing 220 billions of Euros and providing 4,5 million of jobs in Europe, a figure that should double by 2020. Future developments in the sector, together with greater intra-European mobility of workers and population aging brings a greater need for new skills in the work force together with an urgency for a larger number of professionals. Therefore, to achieve the desirable sustained growth the EU needs to invest in high quality VET (Vocational Education and Training) in order to be able to supply the AI (Aeronautic Industry) with qualified workers. VET stands for education and training which aims to equip people with knowledge, know-how, skills and/or competences required in particular occupations or more broadly on the labour market. This paper presents the initial results of an "initiative" supported by the European Commission called AIRVET. Its main objective is to design, develop, evaluate and disseminate adapted/new AI curricula and VET courses in the specific fields of Maintenance and Information and Communications Technologies (ICT). The methodology followed included an analysis of a desk study, questionnaires completed by over five hundred people, focus group meetings held in four countries and individual interviews performed in the six partner countries. The project triangulates the results to establish clear areas that would benefit from the development of vocational training. Three subject areas were identified to be explored in terms of developing/adapting training curricula and developing multimedia training materials: maintenance, ground operations and human factors.
\end{abstract}

Keywords: (Vocational Education Training), Aeronautic Industry, Skills Needs/ Skills Gaps, Curricula, Multimedia Resources

\section{Introduction}

As was recently discussed at a UK Education and Skills meeting organised by the Royal Aeronautical Society (RAeS) the financial importance of the aerospace industry to the European economy is significant [1]. The Aviation Industry is estimated to be worth 4.5 Trillion dollars by 2030 [2], and Airbus forecasts that in the period 2014-2033, approximately 31,000 passenger aircraft are required at a value of $\$ 4.6 \operatorname{tr}$ [3].

Aeronautic industry is recognized by the high-level skilled professionals it engages. Main job positions involve engineers and maintenance technicians trained at the highest level. However, studies show [4] that $85 \%$ of its direct employment is concentrated in $5 \mathrm{EU}$ countries and the ageing of EU population threatens the availability of qualified personnel, emerging in skill shortage sector. Some of the most important industry's problems today are related to skills gaps in current employees as well as the requirement to attract more people into the industry [5].

The industry is constantly developing technology to improve aircraft performance and the efficiency of the operation of airports and aircrafts. This need for a growing number of trained personal can be further seen in statements made by most of the large aviation companies, such as Airbus that: "... has a proactive approach to working with Universities around the world to support the development of future talent. This includes implementing strategic programmes such as the 
Airbus University Board as well as engaging with relevant academic and student networks" [6].

To achieve the desirable sustained growth, the Aeronautic Industry highly depends on the availability of flexible and high-skilled labor force. The overall performance of Aerospace education and training must be improved and a balance between initial and continuous education and training has to be established [7].

\section{Designing and Developing New VET Curricula to Address Skills Gaps in the Aeronautical Industry}

EU needs to invest in high quality VET (Vocational Education Training) in order to be able to supply the AI (Aeronautic Industry) with qualified workers [8, 9]. EU aeronautics industry needs to be considered as a global industry rather than a national one and mobility of workers is undeniable. A close cooperation among VET systems from different EU countries is also desirable $[10,11]$, to face up new challenges for the educational/training areas:

- Improvement of the overall performance of education and training $[12,13]$

- Close cooperation among VET (Vocational Education and Training) systems from different EU countries;

- Better balance between initial and continuous vocational training;

- Full use of knowledge and skills acquired in both formal and non-formal settings.

The AIRVET (Aeronautic Industry Skills Resolution for a more Efficient VET Offer) project is a Long Life Learning initiative financed by the European Commission to prepare industry and society to face challenges identified hereafter.

Its main objective is to design, develop, evaluate and disseminate adapted/new AI curricula and VET courses in the specific fields of Maintenance and Information and Communications Technologies (ICT) [14].

The main results expected by AIRVET are:

- Identification of training and regulatory frameworks, and training gaps and opportunities for the development of VET curricula and training initiatives.

- Design of Curricula and multimedia resources for training based on innovative ways of delivering VET e.g: Learning based games, 2D/3D graphics, low cost simulations, virtual reality, etc.

- Delivering the Curricula by Developing Pilot Runs, practical learning sessions in which the dynamic solutions will be tested in order to collect opinions from both the trainers and the participants on the educational programmes and innovative learning approaches.

\section{Phases and Activities}

AIRVET is implementing a series of activities and producing outputs for different target groups. The work plan has three main phases, summarized in Table 1, and includes open channels of communication through online tools and a series of events to assess the projects product with stakeholders of the industry and to disseminate the project. Project phases, outcomes and events are summarized in Figure 1.

Table 1. Phases for VET improvement.

\begin{tabular}{lll}
\hline Phase & Main Output & Short Description \\
\hline Analysis of skills needs & Territorial Analysis & Collection of training needs involving the stakeholders of the sector \\
Curricula Design & AI Training Curricula & AI Maintenance and ICT Training Curricula/ Programme \\
Curricula Delivery & Multimedia Resources & Multimedia Resources for Training (minimum 3)+ User's Guide Manual \\
\hline
\end{tabular}
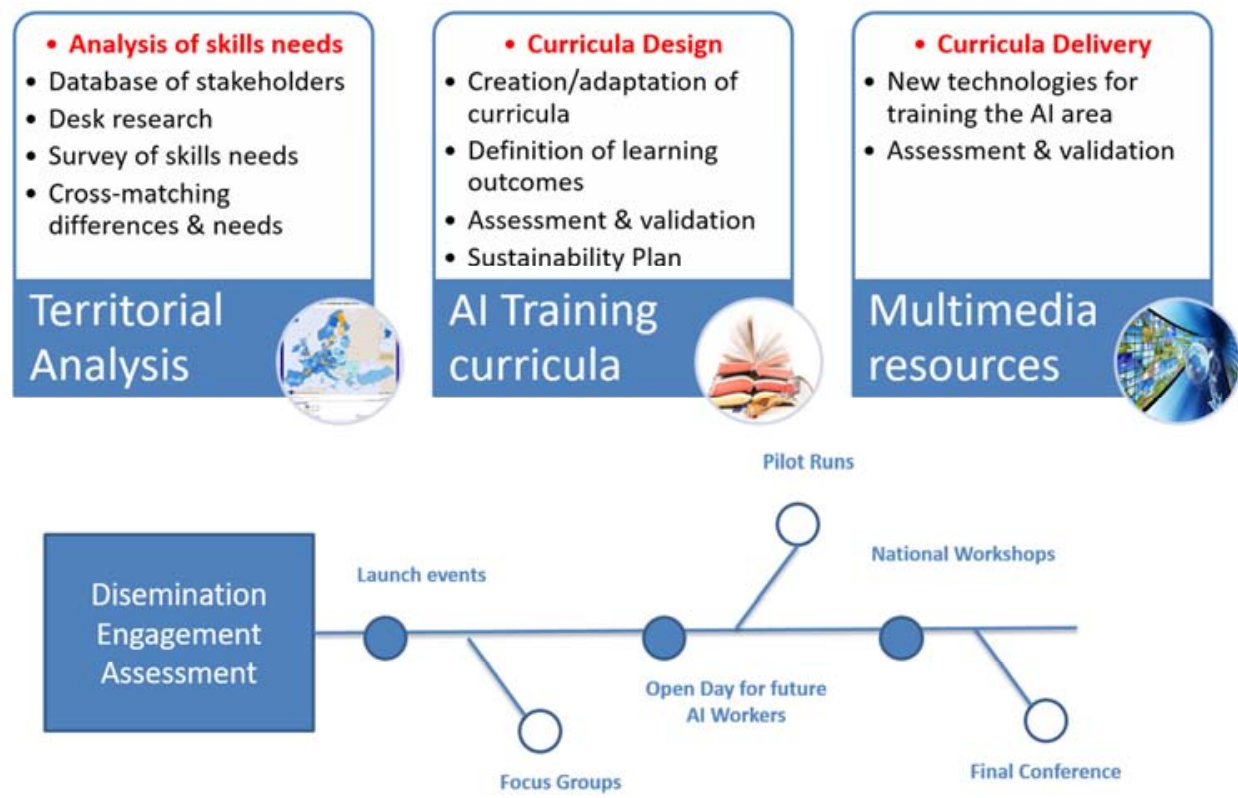

Figure 1. Phases, outcomes and events of the ARIVET initiative. 


\section{Methodology: Territorial Analysis of Skills Needs}

The initial outcome of the project has consisted in an extensive work to identify the training and regulatory frameworks, as well as the training gaps and opportunities for the improvement and development of VET curricula and training initiatives.

The methodology undertaken aimed to identify potential areas of training gaps, curricula that need to be developed or updated or training materials where improvements could be achieved. The work carried out to investigate these issues, named "Territorial Analysis", was split into three components, as illustrated on Figure 2:
- A desk study to identify and analyse the current VET programmes offered in the airline industry in Europe, and determine the principal EU regulations that structured the training in the aviation industry and identify skill gaps;

- A questionnaires study to sought views directly from practitioners to obtain information on their views of skills needs and skills gaps, current training available and methods of training delivery;

- A focus groups on skills needs study to foster face-face discussion among agents in the aviation industry using the preliminary results obtained from the desk research and questionnaire analysis.

\section{TERRITORIAL ANALYSIS}
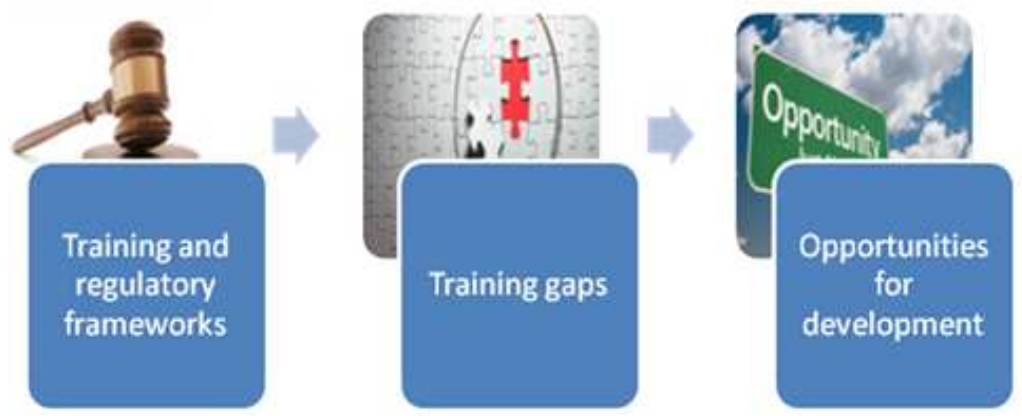

Desk Study

Focus Group

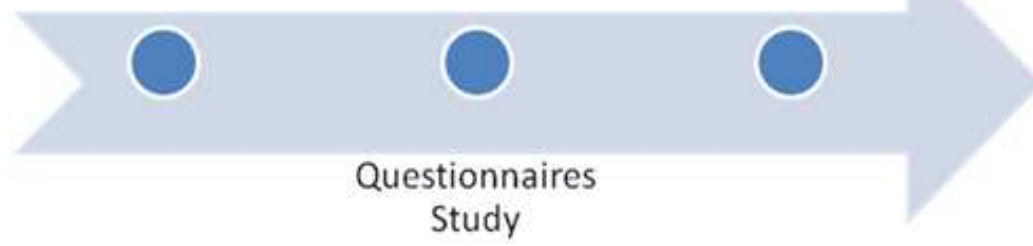

Figure 2. Phases, outcomes and events of the AIRVET initiative.

\subsection{Desk Study Analysis}

The desk study was wide-ranging and addressed many aspects of the aviation industry including air traffic management, airlines and airport operations. It has brought the following conclusions:

- The training of pilots and air traffic control personal and Cabin crew training is highly regulated and supplemented by frequent in-house training. There was no evidence of skills gaps, which was expected in these high safety critical roles.

- For airport operations, although there are several international bodies that promote and endorse aviation training, there are also many roles that require unregulated training that is carried out by the airport companies. In many countries, especially those without a large aerospace industry, there are few opportunities for people to find out about the career opportunities within airports. This gap leaves potential employees uninformed about the opportunities available. The creation of open-source training materials that could be used outside of an airport training centre may be beneficial in increasing recruitment, but also providing new employee's basic knowledge of how an airport operates.

- Manufacturing skills are normally obtained via an apprenticeship and countries usually have their own defined systems. It is not clear what additional training companies deliver and they rarely publish information on specialised courses they operate. The 
gap mainly discussed in the literature is the lack of new entrants. Materials to inform and enthusiasm the youth to engage in apprenticeships would be beneficial.

- The training of the people who maintain aircrafts is regulated at EU level. It is unlikely that this project could influence the training undertaken, but it could produce materials that can be used to enhance training, an example being for those opting to carry out self-learning.
There were some skills gaps identified in the field of human factors applied to maintenance activities

\subsection{Questionnaire Study Analysis}

To perform the questionnaire study, stakeholders were subdivided into four categories as shown in Figure 3. The questionnaire were bespoke designed, as indicated in Table 2, considering each stakeholder group characteristics.

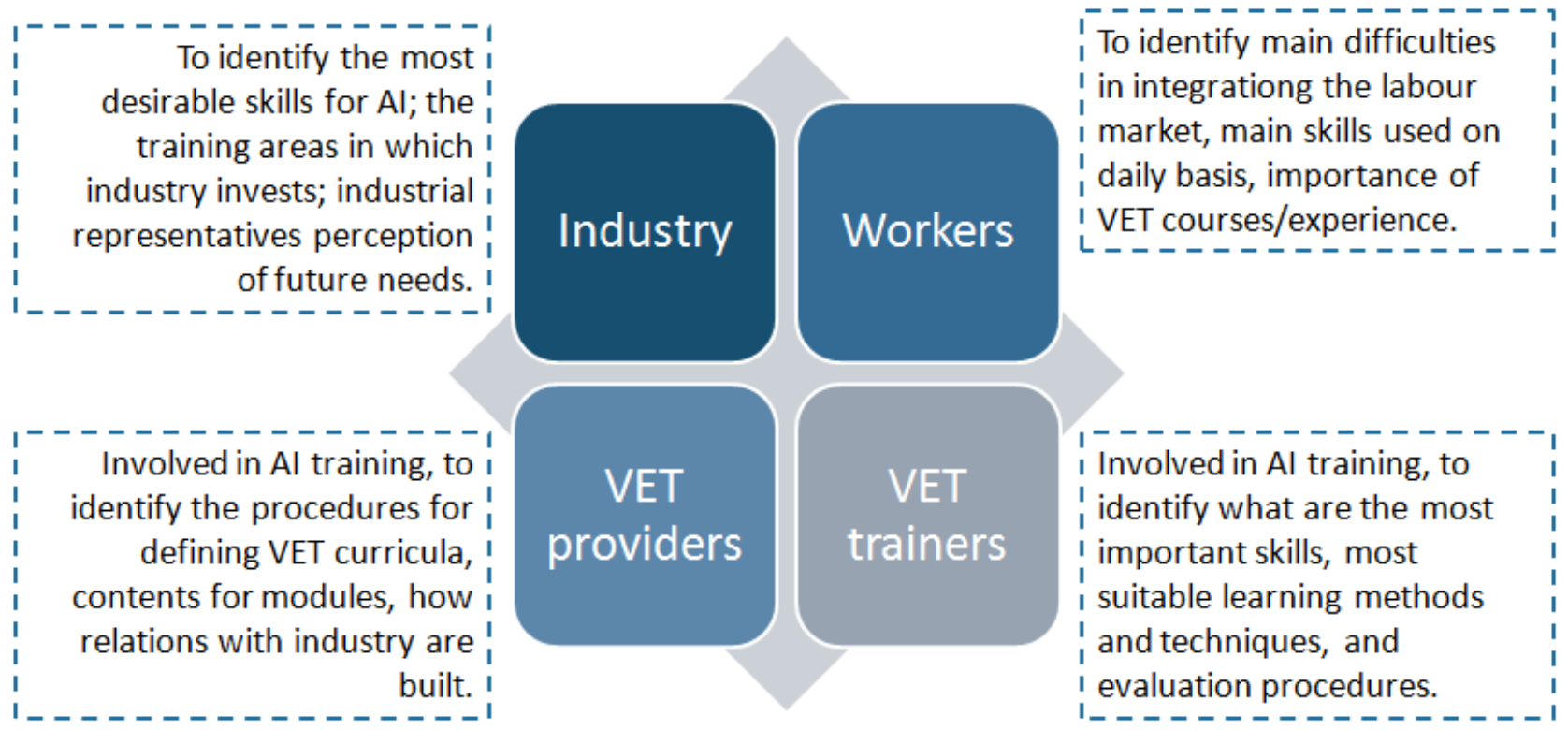

Figure 3. Stakeholder categories and specific survey areas which (AI= Aviation Industry).

Table 2. Set of questions pose to the different groups.

\begin{tabular}{|c|c|c|c|c|}
\hline Question Categories & Workers & Industry (Managers) & VET Providers & VET Trainers \\
\hline \multicolumn{5}{|l|}{ Demographics } \\
\hline Company background & $\begin{array}{l}\text { Operating country } \\
\text { Company size } \\
\text { Workers role } \\
\text { Age }\end{array}$ & $\begin{array}{l}\text { Operating country } \\
\text { Company size } \\
\text { Company function }\end{array}$ & $\begin{array}{l}\text { Operating country } \\
\text { Aerospace activity }\end{array}$ & $\begin{array}{l}\text { Operating country } \\
\text { Aerospace activity }\end{array}$ \\
\hline Worker background & $\begin{array}{l}\text { Work experience } \\
\text { Education background }\end{array}$ & & & \\
\hline Training related to soft skills & Training experience & Training provision & Courses run & Courses run \\
\hline Training related to technical skills & Training experience & Training provision & Courses run & Courses run \\
\hline $\begin{array}{l}\text { Training delivery method } \\
\text { (tradition, CBT, blended, etc.) } \\
\text { Skill gaps \& training development }\end{array}$ & $\begin{array}{l}\text { Training received and } \\
\text { preferred }\end{array}$ & & Training provided & Training provided \\
\hline General areas of skills gaps & Training needed & Skill gaps identified & Skill gaps description & Skill gaps description \\
\hline $\begin{array}{l}\text { Future skills gaps identification } \\
\text { and training development }\end{array}$ & $\begin{array}{l}\text { Preferred training delivery } \\
\text { method }\end{array}$ & $\begin{array}{l}\text { Future skills gap } \\
\text { description }\end{array}$ & $\begin{array}{l}\text { Course development } \\
\text { drivers }\end{array}$ & $\begin{array}{l}\text { Course development } \\
\text { drivers }\end{array}$ \\
\hline
\end{tabular}

\subsubsection{Survey Circulation and Response}

An intensive survey questionnaire distribution campaign was put in place to maximize its circulation across the European aviation industry and to ensure a wide range of aviation industry workers and professionals reaction. Population been reached by the questionnaire distribution campaign it was roughly around 16.500 persons distributed as summarized in the Table 3, distinguishing among "primary readers" (persons directly reached) and "secondary readers" (resulting from circulation of the survey inside companies and institutions). 
Table 3. Population reached by the questionnaire distribution.

\begin{tabular}{|c|c|c|c|}
\hline Distribution medium & Primary readers & Secondary readers & Global targets \\
\hline AIRVET Website & $\begin{array}{l}1000 \\
\text { Estimated figure through the number of visits on the web page. }\end{array}$ & & 1000 \\
\hline Direct email approaches & $\begin{array}{l}2085 \\
\text { Two thousand and eighty five emails were sent. } \\
200\end{array}$ & & 2085 \\
\hline Paper Copy distribution & $\begin{array}{l}\text { Rough figure (people without access to the online questionnaires, meetings with } \\
\text { aerospace personal, conferences and exhibitions. }\end{array}$ & & 200 \\
\hline Social media & 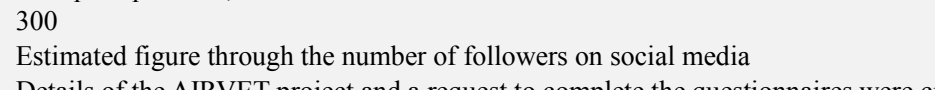 & & 300 \\
\hline $\begin{array}{l}\text { Professional } \\
\text { organisations }\end{array}$ & $\begin{array}{l}\text { Details of the AIRVET project and a request to complete the questionnaires were c } \\
\text { The Chartered Institute of Logistics and Transport (UK) magazine bulletin } 1030 \\
\text { It was distributed to all members (approximately 1030) readers. } \\
\text { The Institution for the Development of Vocational Training for Workers (Italy) } \\
\text { (published in the EuroGuidance newsletter) } 617 \text { members } \\
\text { A stand at the 'Futures Day' at Farnborough Airshow (Farnborough, 2014).32 [17] } \\
\text { EU training organisations represented }\end{array}$ & $\begin{array}{l}\text { irculated by professional orga } \\
1500 \text { (Chartered Institute } \\
\text { of Logistics and Transport, } \\
2015)[15] \\
10000 \text { (Euroguidance, } \\
2010)[16] \\
320\end{array}$ & $\begin{array}{l}\text { anizations such as: } \\
2530\end{array}$ \\
\hline $\begin{array}{l}\text { Total number of targets } r \\
\text { information }\end{array}$ & $\begin{array}{l}\text { eached by the questionnaire survey Primary readers } \\
5.264 \\
\end{array}$ & $\begin{array}{l}\text { Secondary readers } \\
11.820\end{array}$ & $\begin{array}{l}\text { Total } \\
17.084 \\
\end{array}$ \\
\hline
\end{tabular}

For the evaluation of the number of questionnaires answered two indicators were considered:

- Actual Number of Responses or ANR that stands for the total number of responses gathered without making any consideration of the origin of such an answer. The total number of survey respondents was 519 representing 17 EU countries.

- Equivalent Number of Responses or ENR that stands for the weighted amount of responses taking into account the number of individuals represented by a single answer if this one have been provided by an industry or VET provider manager.

Survey demographics summarizes how the distribution of responses obtained from EU countries varied by stakeholder group. The greatest number of responses was obtained from the industry workers (350 responses), and 81 responses were received from industry mangers. Responses from VET providers and trainers were very similar with 46 from VET providers and 42 from trainers. Although only two responses were obtained from UK VET providers, these were from the Aviation Skills Partnership (ASP) and SEMTA, which are the two key bodies. The majority of responses were obtained from the partner countries ( $95 \%$ of the responses). Response rates in France, Portugal and the UK were fairly even (6-9\%) while responses from Italy were slightly higher (12\%). The majority of responses from industry workers and managers were from people working in large companies with greater than 200 employees (39\% and 59\% respectively). Representation from small companies was only $11 \%$ and $10 \%$. Those data and how they have been used to build the weighted indicator Equivalent Number of Responses or ENR are illustrated in Table 4.

Table 4. Equivalent Number of Responses or ENR.

\begin{tabular}{|c|c|c|c|c|c|c|c|c|c|c|}
\hline \multicolumn{11}{|c|}{ CHALLENGING SELECTION OF WEIGHT FACTORS } \\
\hline \multirow{2}{*}{$\begin{array}{l}\text { Company } \\
\text { size }\end{array}$} & \multirow{2}{*}{$\begin{array}{l}\text { Challenging } \\
\text { Weight factor }\end{array}$} & \multicolumn{4}{|c|}{ Absolute number of responses } & \multicolumn{4}{|c|}{ Weighted number of responses } & \multirow{2}{*}{$\begin{array}{l}\text { Total Weighted } \\
\text { Number of } \\
\text { Responses } \\
\end{array}$} \\
\hline & & $\begin{array}{l}\text { Industry } \\
\text { Workers } \\
\end{array}$ & \begin{tabular}{|l|} 
Industry \\
Managers \\
\end{tabular} & $\begin{array}{l}\text { VET } \\
\text { Providers } \\
\end{array}$ & $\begin{array}{l}\text { VET } \\
\text { Trainers }\end{array}$ & $\begin{array}{l}\text { Industry } \\
\text { Workers }\end{array}$ & \begin{tabular}{|l|} 
Industry \\
Managers \\
\end{tabular} & $\begin{array}{l}\text { VET } \\
\text { Providers } \\
\end{array}$ & $\begin{array}{l}\text { VET } \\
\text { Trainers } \\
\end{array}$ & \\
\hline$<10$ & 5 & 35 & 9 & 5 & 4 & 35 & 45 & 25 & 4 & 109 \\
\hline $11-50$ & 25 & 70 & 20 & 12 & 8 & 70 & 506 & 288 & 8 & 872 \\
\hline $51-200$ & 100 & 39 & 20 & 12 & 5 & 39 & 2025 & 1150 & 5 & 3218 \\
\hline$>200$ & 200 & 207 & 32 & 18 & 25 & 207 & 6318 & 3588 & 25 & 10137 \\
\hline \multirow[t]{2}{*}{ TOTAL } & & 350 & 81 & 46 & 42 & 350 & 8894 & 5051 & 42 & $\mathrm{ENR}=14337$ \\
\hline & \multicolumn{10}{|c|}{ CONSERVATIVE SELECTION OF WEIGHT FACTORS } \\
\hline \multirow{2}{*}{$\begin{array}{l}\text { Company } \\
\text { size }\end{array}$} & \multirow{2}{*}{$\begin{array}{l}\text { Conservative } \\
\text { Weight factor }\end{array}$} & \multicolumn{4}{|c|}{ Absolute number of responses } & \multicolumn{4}{|c|}{ Weighted number of responses } & Total Weighted \\
\hline & & $\begin{array}{l}\text { Industry } \\
\text { Workers } \\
\end{array}$ & $\begin{array}{l}\text { Industry } \\
\text { Managers }\end{array}$ & $\begin{array}{l}\text { VET } \\
\text { Providers }\end{array}$ & $\begin{array}{l}\text { VET } \\
\text { Trainers }\end{array}$ & $\begin{array}{l}\text { Industry } \\
\text { Workers } \\
\end{array}$ & $\begin{array}{l}\text { Industry } \\
\text { Managers }\end{array}$ & $\begin{array}{l}\text { VET } \\
\text { Providers } \\
\end{array}$ & $\begin{array}{l}\text { VET } \\
\text { Trainers }\end{array}$ & $\begin{array}{l}\text { Number of } \\
\text { Responses }\end{array}$ \\
\hline$<10$ & 5 & 35 & 9 & 5 & 4 & 35 & 45 & 25 & 4 & 109 \\
\hline $11-50$ & 10 & 70 & 20 & 12 & 8 & 70 & 203 & 115 & 8 & 396 \\
\hline $51-200$ & 50 & 39 & 20 & 12 & 5 & 39 & 1013 & 575 & 5 & 1631 \\
\hline$>200$ & 100 & 207 & 32 & 18 & 25 & 207 & 3159 & 1794 & 25 & 5184 \\
\hline TOTAL & & 350 & 81 & 46 & 42 & 350 & 4419 & 2509 & 42 & $\mathrm{ENR}=7320$ \\
\hline
\end{tabular}


Workers

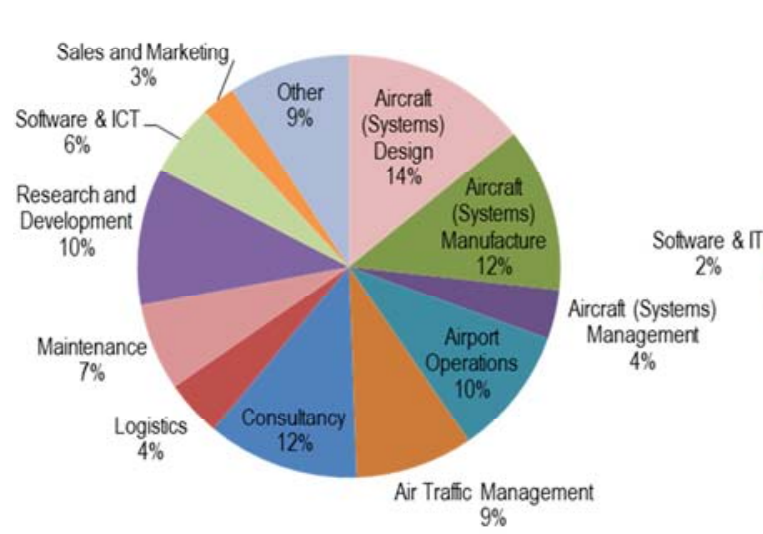

Managers

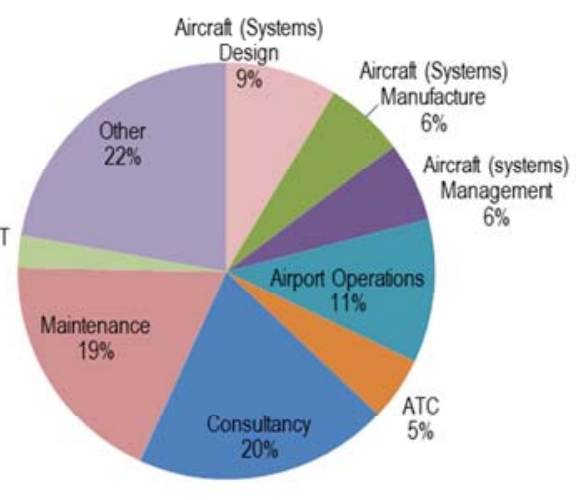

Figure 4. Distribution of aircraft industry companies responding to survey.

Based on industry data [17], it was concluded that the proportion of responses between managers and workers obtained through the questionnaire was similar to that existing within European companies. In European industry the distribution between managers and workers accounts to approximately $7 \%$ managers and $93 \%$ workers. In the survey, the results show that the $12.5 \%$ of the people asked were managers and the $87.5 \%$ of them workers.

Nevertheless, the survey could give a bit biased overview of the whole industry because there were countries with a strong aerospace industry, like Germany, France or United Kingdom with little representation in the survey, and countries with a weak aerospace industry with have had a larger representation in the responses, like the case of Poland, (See Table 5).

Table 5. Relationship between weight of responses obtained and real participation of labour force in the Aeronautical Industry by country.

\begin{tabular}{|c|c|c|c|c|}
\hline Country & Respon-dents & $\%$ of total & x1000 employees in the sector & $\%$ of total \\
\hline Netherlands & 3 & $0,58 \%$ & 15,77 & $3,14 \%$ \\
\hline Spain & 86 & $16,57 \%$ & 38,13 & $7,59 \%$ \\
\hline France & 20 & $3,85 \%$ & 143,2 & $28,49 \%$ \\
\hline UK & 35 & $6,75 \%$ & 103,78 & $20,65 \%$ \\
\hline Poland & 200 & $38,53 \%$ & 14,05 & $2,80 \%$ \\
\hline Italy & 24 & $4,62 \%$ & 41,6 & $8,28 \%$ \\
\hline Portugal & 30 & $5,78 \%$ & 5 & $0,99 \%$ \\
\hline Sweden & 1 & $0,19 \%$ & 8,25 & $1,64 \%$ \\
\hline others & 114 & $21,97 \%$ & 37,74 & $7,51 \%$ \\
\hline
\end{tabular}

In other terms, according to the responses obtained in the questionnaire concerning worker's qualification, $74 \%$ of people who answered the questionnaire have a university degree, $14 \%$ have college education, $6 \%$ school education and $6 \%$ other. When comparing this to the actual situation of the industry, in the European aerospace sector the percentages are quite different. Only $38 \%$ of workers have university education, while $41 \%$ of them have technical education and
$21 \%$ have other education.

\subsubsection{Training Experiences}

The majority of aircraft industry workers have attended job's related training courses in the last 3 years $(96 \%)$. Of these training events, workers reported that $48 \%$ were in subjects related to soft skills and $52 \%$ in technical areas as illustrated in Figure 5.

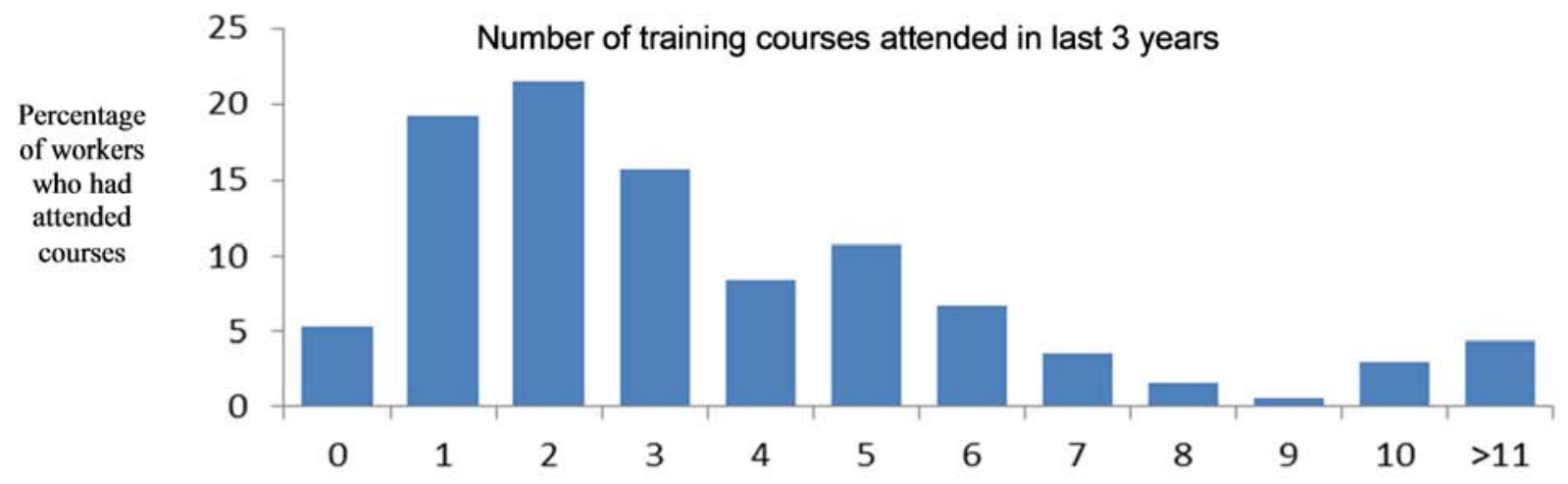

Figure 5. Number of training courses attended by workers over the last 3 years. 
Of the soft skills training received, the highest reported area was health and safety ( $20 \%$ of courses attended). Team working, communication skills, data protection, general, project and risk management were the next popular and ranged between $7-12 \%$ of courses. This distribution was very similar to that provided by the management, with $13 \%$ of the courses provided in health and safety and team working, communication skills, data protection, general, project and risk management each accounting for $8-11 \%$ of provision (See Figure 6).

Training in soft skills is delivered by both VET providers and trainers. However, while $43 \%$ of courses delivered by VET providers are in soft skills, only $32 \%$ of courses delivered by VET trainers are in soft skills, as can be seen in Figure 7.

Technical skills courses attended by industry workers were fairly evenly distributed across the categories surveyed, as can be observed in Table 6 . Courses related to safety, security and human factors were most frequently attended. This was reflected by the training courses being provided by management.

\section{Workers}

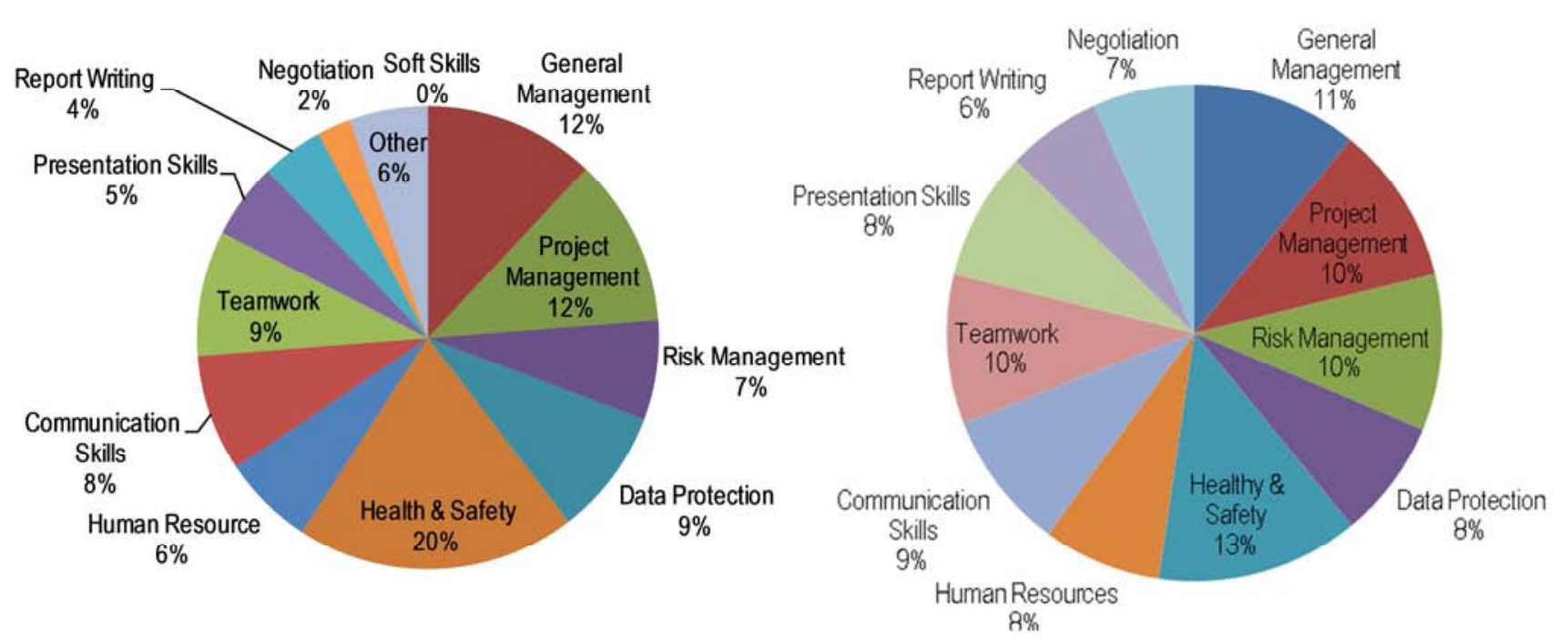

Figure 6. Distribution of soft skills training courses attended by workers and provided by managers.

\section{VET Provider}

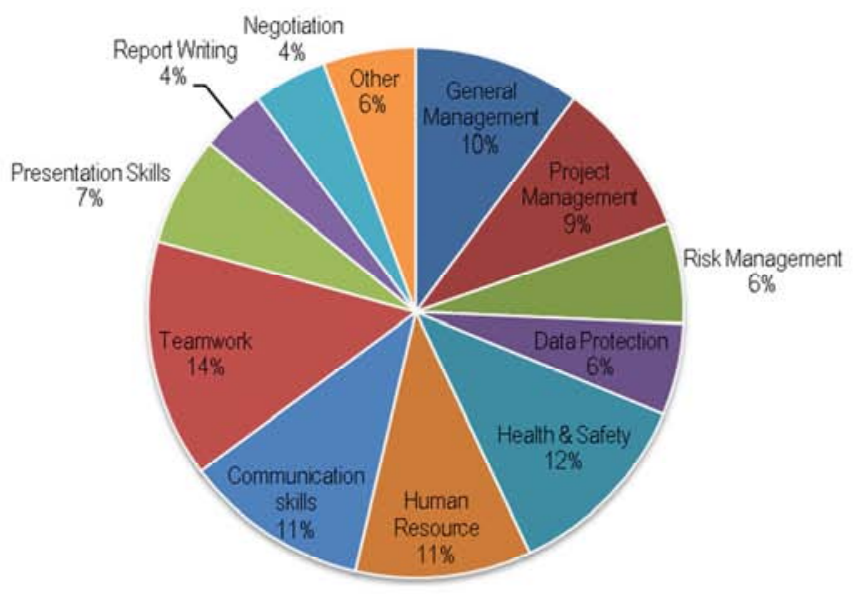

\section{VET Trainer}

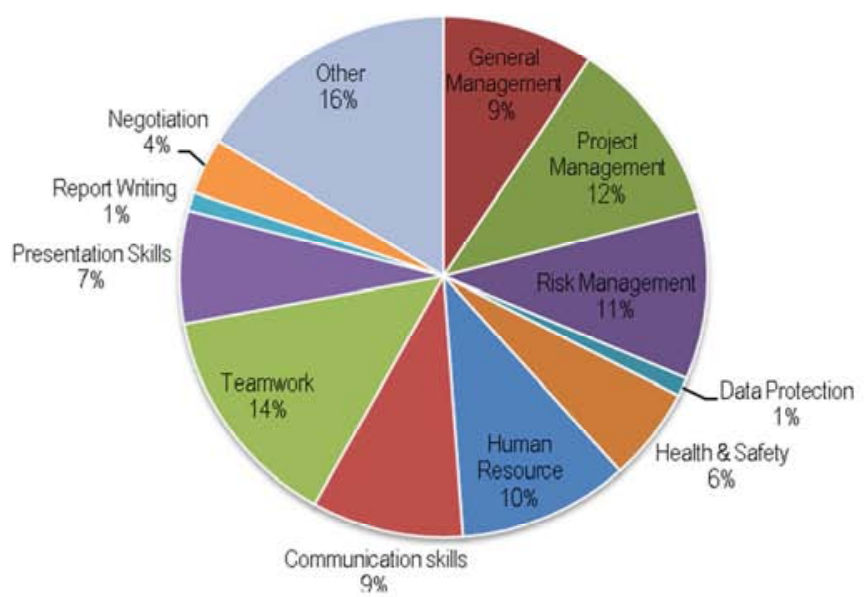

Figure 7. Distribution of soft skills training courses provided by VET Providers and VET Trainers. 
Table 6. Technical skills training courses provided by industry management and attended by workers.

\begin{tabular}{lll}
\hline Technical Skills & Total number of courses undertaken by workers & Total number of courses offered by management \\
\hline ICT maintenance / Logistics services & 51 & 15 \\
Workshop practice & 56 & 30 \\
Human factors & 95 & 45 \\
CAD/CAM & 22 & 31 \\
Stress analysis & 29 & 28 \\
Aircraft design & 45 & 10 \\
Cargo handling systems & 20 & 13 \\
Aerodynamics & 32 & 19 \\
Airport emergency procedures & 43 & 31 \\
Aircraft ground handling systems & 26 & 26 \\
Airport/Aircraft regulations & 66 & 41 \\
Aircraft maintenance procedures & 38 & 35 \\
Aircraft maintenance equipment & 25 & 29 \\
Air traffic control & 55 & 25 \\
Aircraft manufacturing & 20 & 15 \\
Airport operations & 44 & 31 \\
Airworthiness & 46 & 39 \\
Research and development & 43 & 24 \\
Safety & 105 & 54 \\
Security & 51 & 46 \\
Other & 62 & \\
\hline
\end{tabular}

The distribution of courses delivered by VET providers and VET trainers in technical skills are shown in Figure 8. Course provision was rather evenly distributed across the categories surveyed. Aircraft regulation and maintenance accounted for a major percentage of courses provided (19\% providers, $22 \%$ trainers). In terms of specific subjects, human factor training was the largest provision in both groups (providers $11 \%$, trainers 9\%).

\subsubsection{Current Possible Skills Gaps: Identification and Training Development}

The areas of training gaps identified by the managers are shown in Figure 9. The top four predefined list categories are:

- ICT Maintenance/Logistics.

- Airport Emergency Procedures.

- Air Traffic Control.

- Ground Handling Systems.

The skills gaps results shown in Figure 10 identify the subject areas where VET Providers and VET trainers have emphasized the need for training materials. The majority of
VET Providers believed there is a requirement for maintenance equipment and ICT documentation with an equal percentage for the other common themes. The majority of VET Trainers identified Human Factors as the most significant subject area. ICT maintenance and ATSEP was mentioned in several areas including air navigation and baggage handling indicating the diverse interpretation of this term.

In addition to asking the four groups what they thought were current and future skills gaps, the VET providers were asked what the drivers for the development of new courses were. Figure 11 shows that the majority of the training development $(42 \%$; -) is influenced by requests from the customer/industry. The next largest driver is market research $(18 \% ;-)$.

Both VET providers and trainers indicated that resource issues (manpower, money, lack of time and lack of expertise) were the main reasons why courses were not developed in areas where they had identified gaps (Figure 12).

\section{VET providers}

\section{VET trainers}
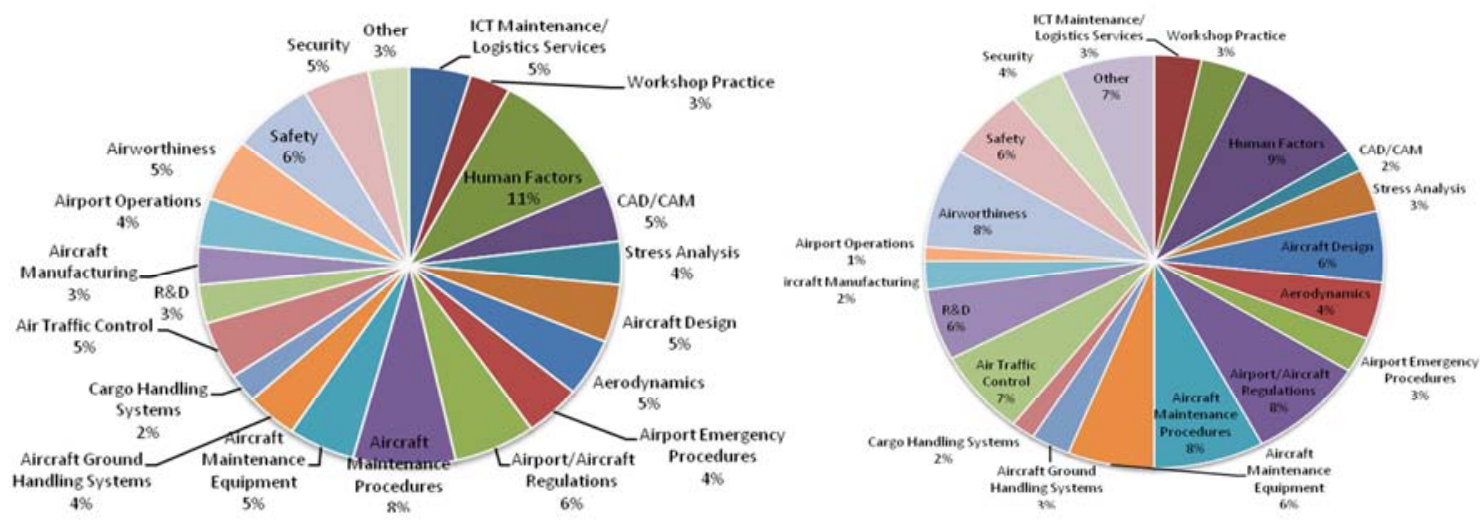

Figure 8. Distribution of technical skills training courses provided by VET providers and trainers. 


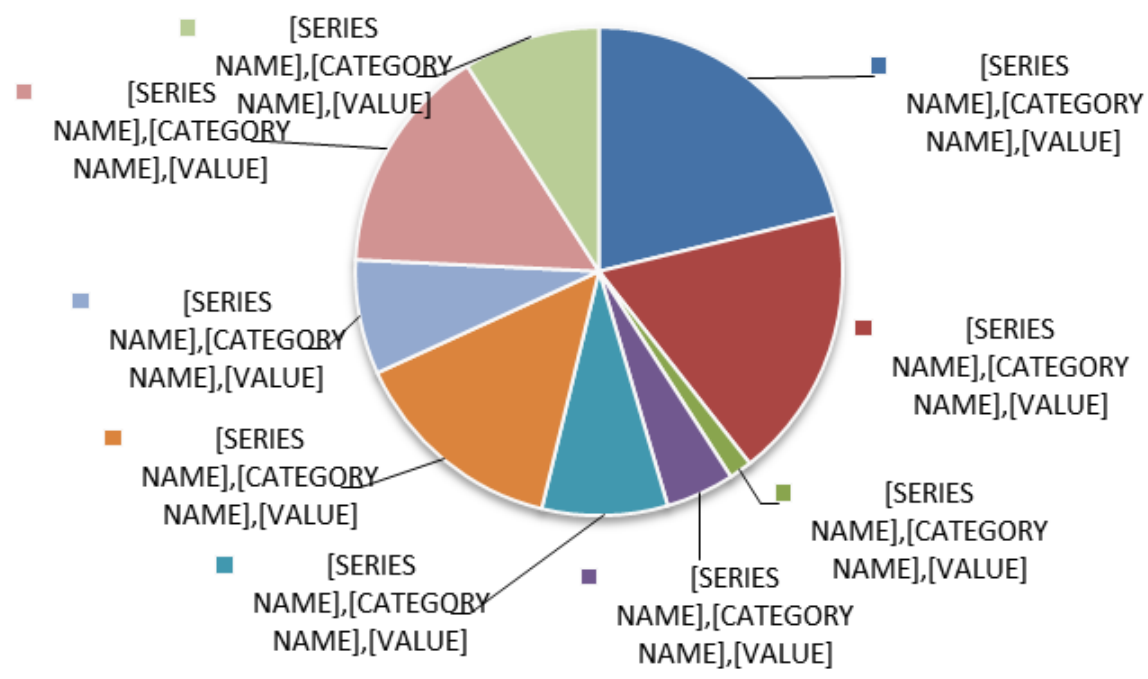

Figure 9. Areas of current skills gaps identified by industry managers.

\section{VET providers}
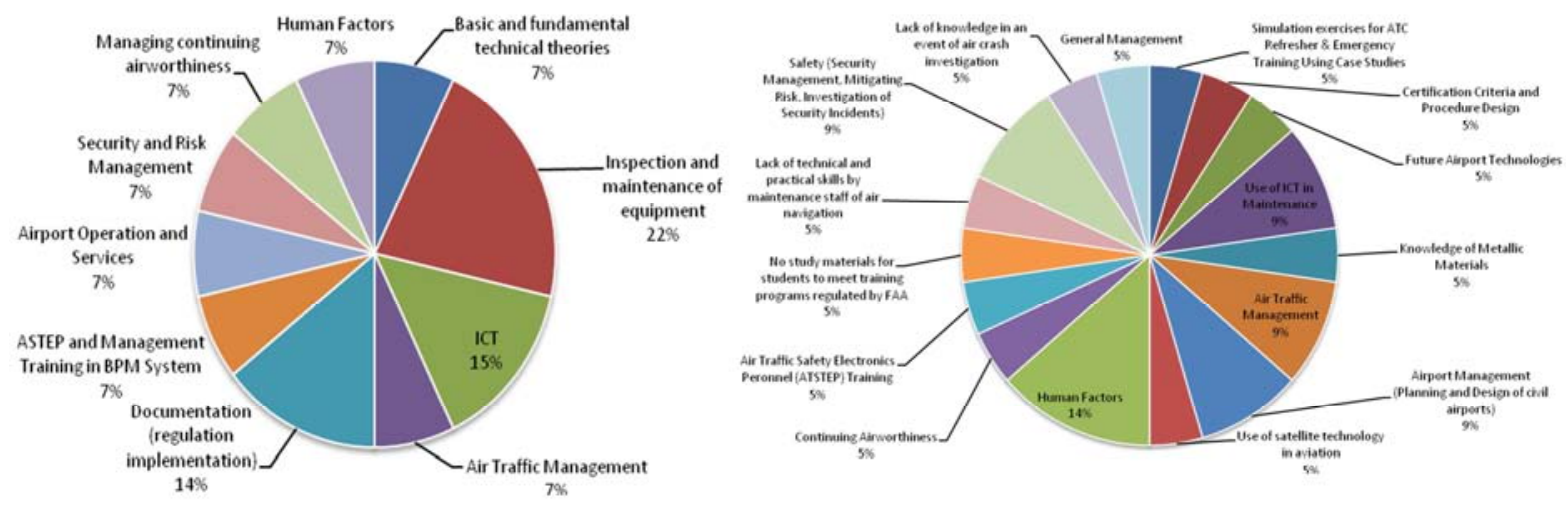

Figure 10. Areas of current skills gaps identified by VET providers and VE trainers.

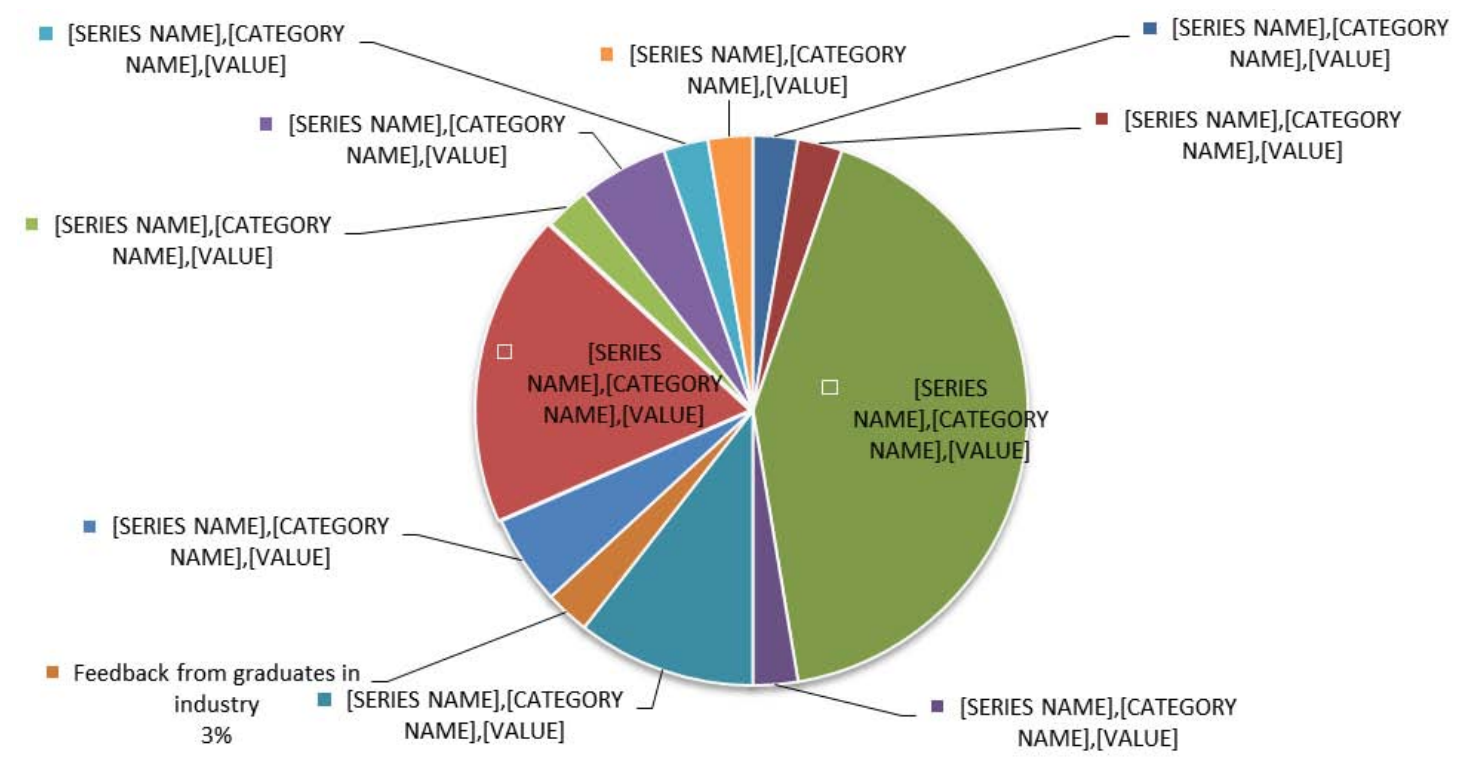

Figure 11. Drivers for the development of new courses as identified by the VET providers. 

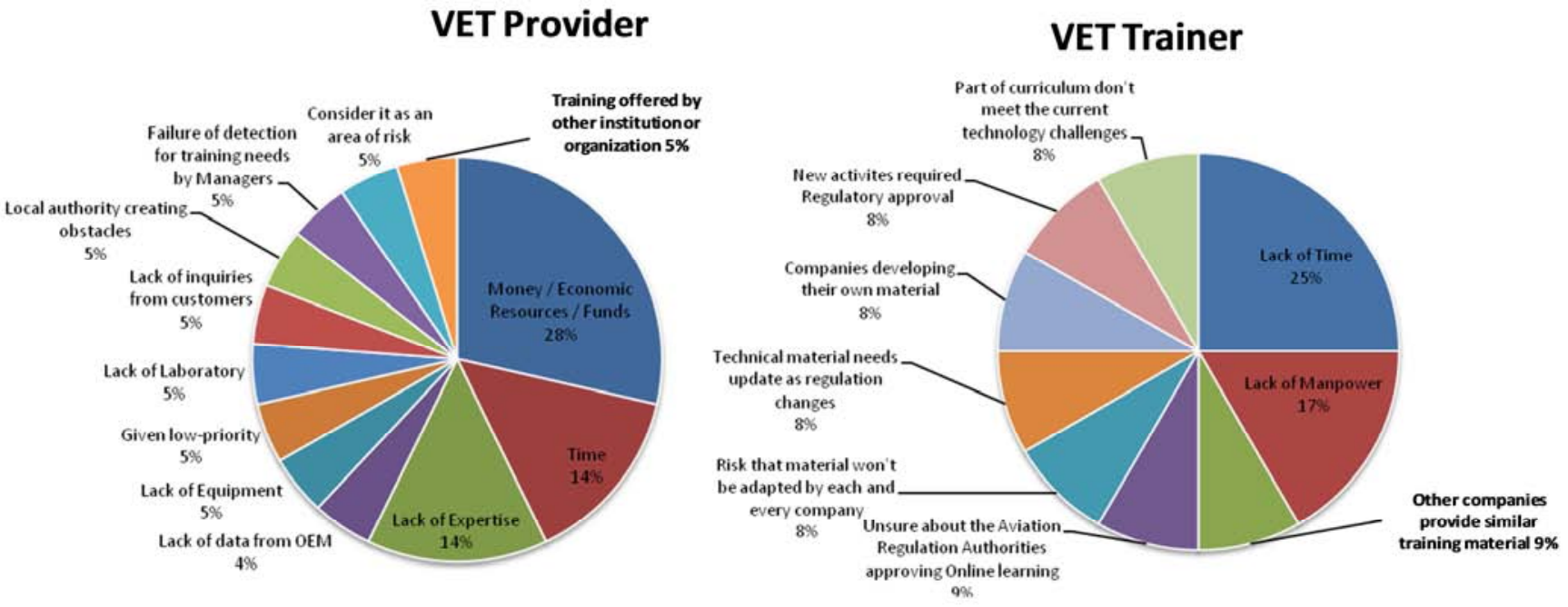

Figure 12. Reasons identified by VET providers and VET trainers why courses are not developed.

\subsubsection{Summary of Training Requirements}

The most frequently identified skills gaps are summarized in Table 7. The first column lists eight general skill gap areas that were most frequently identified. The second column highlights specific topics within these categories. There is some repetition of ATSEP, but this is included and illustrates that certain topics do not fit neatly into a single category.

The main drivers for the development of new courses are meeting the needs of industry and the regulatory bodies. Currently, most courses are taught using traditional methods; however, the workers identified a desire for blended and practical based delivery. A number of skill gaps areas were identified, but human factors and related topics such as safety systems were frequently highlighted as core areas for current training and as a skill gap as a results of the analysis of the responses to the questionnaires.

Table 7. Summary of frequently identified skills gaps (according to the questionnaires results).

\begin{tabular}{|c|c|}
\hline Skills Gap Opportunities & \\
\hline \multirow{3}{*}{ Aircraft Ground Handling } & Baggage/Cargo Handling Systems \\
\hline & Carriage of Dangerous Goods \\
\hline & ATSEP (Air Traffic Safety Electronics Personnel) Training for BPM (Baggage Handling) \\
\hline \multirow{4}{*}{ Aircraft Structural Maintenance } & Composite Material \\
\hline & Repair of Aircraft Structures (Composite Repair) \\
\hline & Repair of Aircraft Structures (Metallic Repair) \\
\hline & Non-Destructive Testing / Inspection of new Composite Materials \\
\hline \multirow{4}{*}{$\begin{array}{l}\text { RPAV/UAS (Remotely Piloted Air } \\
\text { Vehicle) }\end{array}$} & Air Traffic Control / Integration with normal air traffic \\
\hline & New National / European Legislation (particularly with regard to RPAV) \\
\hline & Single European Sky Legislation \\
\hline & Performance Based Navigation \\
\hline \multirow{4}{*}{$\begin{array}{l}\text { SMS (Safety Management } \\
\text { Systems) }\end{array}$} & Training on SMS for aeronautical industry (CAP 760 implementation - FMECA, HAZOP, Event Tree methods) \\
\hline & Aerodrome certification and Safety Management Systems - ICAO Annex 19 \\
\hline & Risk Assessment techniques - identification \& mitigation, \\
\hline & ATSEP (Air Traffic Safety Electronics Personnel) Training \\
\hline \multirow{2}{*}{$\begin{array}{l}\text { Maintenance of specific Airport } \\
\text { Operations }\end{array}$} & Maintenance \& Inspection of equipment for Edge (Light controls) \\
\hline & $\begin{array}{l}\text { Maintenance \& Installation of airport/runway lighting (CAP637 implementation - obstacle lighting \& marking / } \\
\text { aeronautical ground lighting) }\end{array}$ \\
\hline Aircraft Operation & Flight Dispatch Optimisation (optimisation of the scheduling of aircraft maintenance for items not part of the MMEL) \\
\hline $\begin{array}{l}\text { Aeronautical Industry } \\
\text { Introduction }\end{array}$ & $\begin{array}{l}\text { Key concepts and drivers in the aeronautical industry (could be airline, airport or aircraft driven). Provide new workers } \\
\text { with introduction. }\end{array}$ \\
\hline Human Factors & \\
\hline
\end{tabular}

\subsection{Focus Group Study Analysis}

The focus groups generally confirmed that the gaps identified as part of the desk study and questionnaire analysis do exist. They also introduced some new areas of skills gaps. As result they inferred that:

- The main gaps identified with existing employees are associated with the less regulated sections of the industry and airport operations.

- Soft skills as management, communication, presentations are mentioned frequently as an area where further training is needed in the workforce.

- The topic human factors is also mentioned frequently particularly when it is connected with safety.

- The new technology of unmanned aircraft systems was 
an area acknowledged as being one most had little experience with, although people thought more knowledge about these was required.

- The difficulties of being able to recruit appropriately qualified staff and the need to inform school leavers about opportunities in the industry is clearly identified as being of concern.

\section{Conclusions and Future Developments}

This paper illustrates the attempt made by ARIVET project to identify skill gaps and training needs in the aerospace industry focusing mainly on 6 EU countries: France, Italy, Poland, Portugal, Spain and the UK.

Analysis of a desk study, questionnaires completed by over five hundred people, focus group meetings held in four countries and individual interviews were the activities performed in the six partner countries. The project attempted to triangulate the results to establish clear areas that would benefit from the development of vocational training.

The project has also identified and discussed the principal regulations that govern training syllabi. This work resulted in the identification of some skills gaps mainly as a result of changing technologies. These skill gaps may be addressed through a commitment to lifelong learning by employers and employees. The possibility of increasing multimedia presentations to either invigorate teaching or widen the possibilities for knowledge distribution was indicated.

From the desk research a lack of information on skills gaps with employees was found. Many subject areas have been suggested as having skill gaps. The largest training need indicated from the questionnaires was health and safety followed by management and with human factors frequently being mentioned. These three topics overlap particularly human factors with safety systems. It is reassuring that the focus groups confirmed these skill gaps.

Soft skills more than technology based ones were frequently mentioned as being an area to address, whether with existing staff or new entrants. This is possibly because technically skilled people will have received formal training, normally in a regulated environment. For many technically educated people soft skills are experiential in nature and an area in which they receive little formal training.

Three subject areas were identified to be explored in terms of developing/adapting training curricula and developing multimedia training materials in the second year of the AIRVET project: maintenance, ground operations and human factors.

- Maintenance: Considering the seventeen modules in the EASA 'basic licence', topics can be identified that could be used to produce exciting multimedia presentations: Module 12 on helicopter aerodynamics, Module 14 on propulsion, and Module 9 on introduction to human factors. In particular, this last topic has been highlighted throughout this study as one where employees need additional education. Enhanced training materials to support self-learners preparing for assessment or the creation of materials to support training providers could be developed.

- Ground operations: Gaps have been identified in the working knowledge of how an airport functions and how the various roles interact. This gives an opportunity to develop and test learning materials. Many of the comments related to improving knowledge of working safely and awareness of the dangers involved. These fit a human factors agenda that contribute towards helping address a skills gap in ground operations.

- Human factors: Human factors has been highlighted in the literature review, questionnaires, focus groups and individual interviews as an area where workers and managers from the aeronautical industry need additional support and training. This subject has clear applications in maintenance and ground operations. It is worth concentrating on the production of human factor training materials which can unify our project and reach across subject areas and careers.

Finally, the project will contribute with some materials that can be used to help the people and the youth and potential future workers in particular gain an overview of the aerospace industry.

\section{References}

[1] Royal Aeronautical Society UK Education and Skills Seminars. RAeS. London on 30th April 2014.

[2] Bond, D, 2014. Working together to deliver the skills that industry needs RAeS Education and Skills Conference. 1st October 2014 at Royal Aeronautical Society, London.

[3] Airbus, 2014. Flying on demand [online] available from http://www.airbus.com/company/market/forecast/

[4] ASD Media group, 2007. ASD Report.

[5] CBI/Pearson, 2013. Changing the pace available from http://www.cbi.org.uk/media/2119176/education_and_skills_s urvey_2013.pdf

[6] Airbus, 2014a. Commitment to Education [online] available from

http://www.airbus.com/work/early-careers/commitment-to-ed ucation/

[7] Ecorys, 2009. FWC Sector Competitiveness Studies Competitiveness of the EU Aerospace Industry with focus on: Aeronautics Industry Within the Framework Contract of Sectoral Competitiveness Studies. ENTR/06/054 Final Report, Munich, 15 December 2009.

[8] Gordon, Jean, 2015. Glimpsing the Future in the Past: VET in Europe. EUROPEAN JOURNAL OF EDUCATION Volumen: 50,4 (440-460).

[9] McGrath, Simon; Powell, Lesley, 2016. Skills for sustainable development: Transforming vocational education and training beyond 2015. INTERNATIONAL JOURNAL OF EDUCATIONAL DEVELOPMENT Volumen 50 (12-19). 
[10] Arribas, J. Manuel Galvin. 2016. Governance Dynamics and the Application of the Multilevel Governance Approach in Vocational Education and Training (VET) in the European Neighbourhood Countries: the case of the ENPI South region. EUROPEAN JOURNAL OF EDUCATION Volumen: 51, 4 (495-512).

[11] Buligina, Ilze; Sloka, Biruta, 2016. Strategic Partnerships for the Development of Competitive Labor Force Through Vocational Education and Training. 15th Eurasia-Business-and-Economics-Society (EBES) Conference. Volumen: 3-1 (229-244).

[12] Pilz, Matthias, 2016. Typologies in Comparative Vocational Education: Existing Models and a New Approach. VOCATIONS AND LEARNING Volumen 9,3 (295-314)
[13] Toner, Phillip; Woolley, Richard, 2016, Perspectives and Debates on Vocational Education and Training, Skills and the Prospects for Innovation. REVISTA ESPANOLA DE SOCIOLOGIA Volumen 25, 3, (319-342).

[14] Patricia Wastiau et Al. 2013. The Use of ICT in Education: a survey of schools in Europe. European Journal of Education. Volume 48, Issue 1, 11-27.

[15] Chartered Institute of Logistics and Transport, 2015. Logistics \& Transport Focus magazine bulletin.

[16] Euroguidance, 2010 Evaluation. Report in 2010: Education, Audiovisual and Culture Executive Agency. Lifelong Learning: EuroGuidance network Leonardo da Vinci, Grundtvig and Dissemination. Activity Report.

[17] Bsigroup, 2012. Key and figures Aeronautical Industry 2012. 